University of Wollongong

Research Online

Faculty of Commerce - Papers (Archive)

Faculty of Business and Law

Fall 2009

\title{
Desalinated versus recycled water - public perceptions and profiles of the accepters
}

Sara Dolnicar

University of Wollongong, s.dolnicar@uq.edu.au

A. I. Schäfer

University of Edinburgh

Follow this and additional works at: https://ro.uow.edu.au/commpapers

Part of the Business Commons, and the Social and Behavioral Sciences Commons

\section{Recommended Citation}

Dolnicar, Sara and Schäfer, A. I.: Desalinated versus recycled water - public perceptions and profiles of the accepters 2009.

https://ro.uow.edu.au/commpapers/485

Research Online is the open access institutional repository for the University of Wollongong. For further information contact the UOW Library: research-pubs@uow.edu.au 


\title{
Desalinated versus recycled water - public perceptions and profiles of the accepters
}

\begin{abstract}
Many countries' water resources are limited in both quantity and quality. While engineering solutions can now safely produce recycled and desalinated water from non-potable sources at a relatively low cost, the general public is sceptical about adopting these alternative water sources. Social scientists need to better understand what is causing this lack of acceptance by the general population and how acceptance levels for recycled and desalinated water can be increased. This study is the first to conduct a comparative analysis of knowledge, perceptions, acceptability, and determine segments of residents who are more open-minded than the general population toward the use of recycled and desalinated water. The Australian population once perceived desalinated water as environmentally unfriendly, and recycled water as a public health hazard. The general level of knowledge about these two concepts as potential water sources has historically been low. After nearly five years of serious drought, accompanied by severe water restrictions across most of the country, and subsequent media attention on solutions to water scarcity, Australians now show more acceptance of desalinated water for close-to-body uses, and less resistance to recycled water for garden watering and cleaning uses. The types of people likely to be strong accepters of the two alternative water sources are distinctly different groups, and can be reached through different media mixes. This finding has significant implications for policy makers.
\end{abstract}

\section{Keywords}

water recycling, desalination, public perception and acceptance, public knowledge, market segments

\section{Disciplines}

Business | Social and Behavioral Sciences

\section{Publication Details}

Dolnicar, S. \& Schafer, A. (2009). Desalinated versus recycled water - public perceptions and profiles of the accepters. Journal of Environmental Management, 90 (2), 888-900. 
$5 \quad$ Sara Dolnicar ${ }^{a^{*}}$ and Andrea I Schäfer ${ }^{b}$

6

7 a School of Management and Marketing, University of Wollongong, Northfields Ave, 82522 Wollongong, New South Wales, Australia. Email: sara_dolnicar@uow.edu.au, $9 \quad \mathrm{Ph}+61242213862 \mathrm{Fax}+61242214154$

$10{ }^{\mathrm{b}}$ School of Engineering and Electronics, The University of Edinburgh, EH9 3JL, 11 United Kingdom, Email: Andrea.Schaefer@ed.ac.uk, Ph +44 1316507209 Fax +44 $12 \quad(0) 1316506781$

13

$14 *$ corresponding author 15 16 


\section{Desalinated versus recycled water - public perceptions and profiles of the accepters}

Abstract

Many countries' water resources are limited in both quantity and quality. While engineering solutions can now safely produce recycled and desalinated water from non-potable sources at a relatively low cost, the general public is sceptical about adopting these alternative water sources. Social scientists need to better understand what is causing this lack of acceptance by the general population and how acceptance levels for recycled and desalinated water can be increased.

This study is the first to conduct a comparative analysis of knowledge, perceptions, acceptability, and determine segments of residents who are more openminded than the general population toward the use of recycled and desalinated water. environmentally unfriendly, and recycled water as a public health hazard. The general level of knowledge about these two concepts as potential water sources has historically been low. After nearly five years of serious drought, accompanied by severe water restrictions across most of the country, and subsequent media attention on solutions to water scarcity, Australians now show more acceptance of desalinated water for close-to-body uses, and less resistance to recycled water for garden watering and cleaning uses.

The types of people likely to be strong accepters of the two alternative water sources are distinctly different groups, and can be reached through different media mixes. This finding has significant implications for policy makers.

Key words: water recycling, desalination, public perception and acceptance, public knowledge, market segments 


\section{Introduction}

Many countries have increasingly limited water resources in both quantity and quality. Human water consumption has increased beyond sustainable levels in many regions, resulting in extended periods of drought, depletion of environmental flows in natural water systems and the decrease in the quality of drinking water reservoirs, including groundwater systems. High stress regions have traditionally included California, Australia, the Middle East and the Mediterranean (International Water Management Institute (IWMI), 2006).

The global water cycle is a closed system, with water molecules continuously taken in and excreted by living organisms (Suzuki, 1997). Debate is escalating about the acceptance and suitability of human-engineered water recycling within this continuum. Water recycling involves the treatment of municipal wastewater for the replenishment of available freshwater resources. It closes the water cycle on a local level, and enables the closure of water cycles for individual households, buildings, factories, towns, or regions. A range of wastewater treatment technologies is available to achieve recycled water - of a quality that is often superior to existing potable water standards (Bixio et al., 2005; Wintgens et al., 2005). Despite this, the concept of drinking wastewater does not have wide public support. Several public consultation studies explore reasons for this resistance, and how to gain community support (for example, Marks, 2003; Baggett et al., 2006; Marks, 2006). In some instances cultural issues or even spiritual or religious relationships to water are important (Strang, 2004). Recycled water is now available in countries with severe water restrictions, but clients for the product often cannot be found. Several factors combine to hinder recycled water uptake, including inadequate distribution infrastructure for supply, existing highly subsidized and cheap potable water resources, and a low level of community awareness of the limitations of freshwater resources, particularly in urban areas. New problem solving approaches to water supply are needed (Weber, 2006).

Dual reticulation systems are one approach used in Australia (Wintgens et al., 2005; van Roon, 2007), where new developments are fitted with one set of pipes for potable water (conventional tap water) and another for reused water (treated with various technologies, depending on the scheme). Other approaches to promote recycled water acceptance include many countries' implementation of (or plans to implement) seawater desalination to meet the shortfall in drinking water supplies and 
1 avoid public acceptance problems (IDA, 2006). Desalination is well established in some countries, and reuse is considered to be an alternative (Côté et al., 2005). The growth of desalinated water production worldwide is near exponential (Dawoud, 2005), which might be explained by the declining costs of desalination technology, even though it produces water more expensively than does traditional supply (Dawoud, 2005).

Key issues in the desalination debate concern energy consumption, water quality, and environmental impacts. Introducing alternative water schemes (such as recycled, desalinated, storm or grey water), while objectively necessary, indispensable and technically possible, is complicated, because contributions from three sides are required:

(1) Professional knowledge provides the technical foundation to provide safe, reliable, and affordable alternative water source schemes.

(2) The community needs to accept or desire alternative water schemes.

(3) Because public acceptance is typically slow to emerge, it requires an issue management approach to introducing alternative water schemes, which may extend well beyond a specific location and public consultation at that location. Hartley (2006) mentions five crucial dimensions of issues management in the context of water reuse decision making: "managing information; maintaining motivation and demonstrating organizational commitment; promoting communication and public dialog; ensuring a fair and sound decision making process and outcome; and building and maintaining trust." National social marketing campaigns may be necessary to educate the population about the importance (necessity) and possible risks (and opportunities) associated with adopting (and not adopting) alternative water schemes.

This paper discusses all these aspects. A brief background on the professional knowledge on recycling and desalinating water provides the technical knowledge base. Management implications are discussed in the conclusion. However, this paper mainly focuses on evaluating public acceptance of recycled and desalinated water. For this purpose it is necessary to determine: (1) what the main concerns are regarding household use of recycled and desalinated water, (2) how the community currently perceives recycled and desalinated water, (3) the level of factual knowledge, and (4) the stated likelihood of residents to use each of these alternative water sources. 
Where some people state to be more likely to use recycled and desalinated

2 water, it is also valuable to ascertain: (5) what the characteristics of those people are,

3 because they could potentially serve as a market segment for early stages of the

4 introduction of alternative water schemes. We henceforth refer to them as the "strong accepter segment."

Although previous studies extensively examine concerns and levels of public acceptance, very little research investigates the actual knowledge of the population about alternative water sources, as well as people's perceptions of them. Comparisons of knowledge and perceptions of different alterative water sources are rare, and no comparisons of strong accepter segments for different water sources yet exist.

\section{Review of prior research into public perceptions}

The issue of public acceptance of desalinated water has received scant attention. This contrasts with work on acceptance of recycled water, which has taken several directions. The majority of work investigates people's willingness to adopt recycled water (Bruvold and Ward, 1970; Bruvold, 1972; Kasperson et al., 1974; Sims and Baumann, 1974; Stone and Kahle, 1974; Olson et al., 1979; Bruvold et al., 1981; Milliken and Lohman, 1985; Po et al., 2004). Most studies find that the mostopposed use of recycled water was for food preparation and drinking. More than half of respondents (on average across all studies) expressed that they did not want recycled water used for these purposes. However, public uses with less human contact (such as firefighting and irrigation of public spaces) had high public acceptance 23 levels.

Most studies do not include price in their acceptance questions. However, Thomas and Syme (1988) found that the price elasticity for water is generally low, and price increases of conventional water sources have little effect on acceptance levels for recycled water (Baumann and Kasperson, 1974; Bruvold, 1979). In contrast, Kaercher et al.(2003) and Marks et al. (2002) found that cost-benefits are an important criterion for public acceptance. Alhumoud et al. (2003) conclude that

30 Kuwaitis were willing to pay more for their water in order to avoid having to use 31 recycled water. Hurlimann and McKay (2007) found that residents of a community 
1 that already has recycled water available for domestic non-potable use were willing to pay more for recycled water if this would ensure a quality improvement.

Other prior work investigates the concerns and perceived advantages of using recycled water. Bruvold (1988) identifies negative environmental consequences, and economic and health outcomes as concerns. In the context of direct potable use, Dishman et al. (1989) found that public health concerns were central to low acceptance levels. In Australia, Higgins et al. (2002) found that "public health and the environmental effect of microbiological agents," together with chemicals such as endocrine disrupters, were a prime concern. Marks et al. (2002) identify quality and cost as the two main concerns among users. Hamilton (1994) found that opposition to potable reuse schemes derives from the public's suspicion of politicians and organizations involved in the projects. This charged emotional response may be central to understanding public resistance to alternative water sourcing, and may be crucial to communicating to residential users which sources are trusted and which are not.

Few studies investigate the perceived advantages of using recycled water. However, Marks et al. (2002) identify three perceived benefits among users at an Australian site: cost savings, the positive effect on the environment and the nutritional value of reclaimed water.

Several studies identify market segments of likely adopters of recycled water (Hanke and Athanasiou, 1970; Gallup, 1973; Kasperson et al., 1974; Sims and Baumann, 1974; Johnson, 1979; Olson et al., 1979; Carley, 1985; Alhumoud et al., 2003; Hurliman and McKay, 2003). The single personal characteristic found consistently over several studies to be related to stated acceptance levels of recycled water is education, followed by age and knowledge about reuse, then income and gender.

The most comprehensive study of the acceptance of recycled and alternative water uses hitherto is Marks et al. (2006). This study confirms the preference for nonpotable uses, and uniquely includes other alternative water sources compared to recycled water. While not all uses were evaluated for all water options, respondents

31 demonstrated a high willingness to use grey water and stormwater for garden irrigation and toilet flushing. More than half (52 percent) stated that they were willing 
1 without hesitation to use desalinated seawater for all water uses. Experienced users of recycled water in Australia (these represent a very small minority in pilot communities) stated that low levels of salt are the determining characteristic of their acceptance of recycled water for water irrigation, colorlessness for laundry and low price for toilet flushing (Hurlimann and McKay, 2007).

Context is crucial to understanding the stated willingness of the public to adopt water reuse or recycling. Therefore the following section offers a brief summary of the comparative water quality issues, energy consumption, and environmental impacts.

\section{Water quality issues - recycled versus desalinated water}

The primary source of recycled water is municipal wastewater, and this has prompted community concerns about water quality. Seawater is seen as a more pristine source. Wastewater carries what humans excrete and discharge to the drain from sources such as toilet, bathroom, kitchen, and laundry, or miscellaneous dumps of household or garden toxins or pharmaceuticals.

Toze (2006) summarizes the primary concerns as being microorganisms including bacteria, viruses, protozoa, and helminthes, which are excreted from ill persons and carry infectious disease. Such organisms are eradicated by several "barriers" during water recycling, although the risk of treatment failure exists. However, this risk is relatively small and requires the combination of multiple, simultaneous systems failures.

A second concern is the presence of trace organic compounds such as pharmaceuticals or "endocrine disrupting chemicals" (Toze, 2006). According to current knowledge, such compounds do not generally pose an immediate health risk, but can be a chronic risk in cases of long-term exposure, which may cause loss of fertility, affect normal development and behavior functions, contribute to cancer, and other problems of which the real source is more difficult to identify. Other exposure routes for such compounds are food, beverages, contact with chemicals (such as

31 The production of hazardous chemicals is a further concern in treatment, where specific chemicals are often added (such as coagulants and anti-scalants) or by- 
1 products formed during disinfection or oxidation processes. The removal of the majority of such chemicals is possible, but the technical effort is extensive and possibly unnecessary. Guidelines for specific water treatment applications and risk assessments of possible health effects are presently under discussion worldwide. Concerns about water quality and possible systems failures continue to stall the uptake of recycled water for potable purposes, even though many drinking water or groundwater supplies are not presently free of such contaminants.

A technology used for both water recycling and desalination is reverse osmosis. This technology is used commonly for both application and hence lends itself for direct comparison. Reverse osmosis can treat both seawater and wastewater to a quality higher than required for most water applications. This quality achievement is especially relevant where the majority of water consumption is used for irrigation (approximately 70 percent in Australia - see Lake and Bond, 2006). bottled waters. Further, water reuse is rarely considered for "direct potable reuse," although this issue has been left open here.

\section{Energy consumption and cost — recycled versus desalinated water}

Energy constitutes a large portion of the cost of water provision, and is a prime driver of decisions about water and wastewater treatment technology. Generally, the more advanced the treatment and the further it is transported, the more energy is required to supply water. Other cost factors include pre-treatment, chemical addition, cleaning, maintenance, and capital works.

Almost identical technology — reverse osmosis — is commonly applied in large-scale facilities for both water recycling and seawater desalination for potable purposes. The same technology is used in many desalination and water reuse plants, especially in Australia, so it is easily comparable. Depending on the nature of the water to be treated, energy requirements differ. For example, the amount of total dissolved solids (TDS) to be removed from seawater is significant. The TDS concentration of municipal wastewater is usually between $0.1-1 \mathrm{~g} / \mathrm{L}$; while seawater

31 TDS is generally above $35 \mathrm{~g} / \mathrm{L}$, which is 35 to 350 times greater. Reverse osmosis 
1 operates by overcoming the osmotic pressure of water by an applied pressure. Hence, the higher the TDS, the higher the required energy to supply the necessary pressure.

According to Dawoud (2005), 50 percent of the cost of desalinated water is the energy component. Others (Hinkebein and Price, 2005) estimate it at 44 percent for seawater. Côté et al. (2005) estimate energy costs at 33 percent of the total lifecycle cost for desalination, and at four times higher a feed pressure and higher feed flow compared to reuse. They compare desalination with water recycling, and found that both capital costs and operation and maintenance costs were double for the desalination plant, with the overall cost for desalination 2.21 times higher than for reuse (Côté et al., 2005). However, according to Dawoud (2005), the demand for water is greater than that for energy, and this may be one reason for the frequent neglect of energy considerations. Adham et al. (2005) develop a model that estimates the order-of-magnitude desalination costing for three water sources: brackish groundwater, surface water and recycled water (TDS is assumed to be $1 \mathrm{~g} / \mathrm{L}$ for each). Power costs are linear with plant capacity, and represent about 25 percent of the operational cost, where the cost for brackish water desalination is about 50 percent of water recycling. Unfortunately, no seawater data is available in this comparative study.

Adham et al. (2005) note that power costs are the most important and volatile component of such systems. In a very comprehensive cost comparison, Dreizin (2006) describes water recycling and brackish water desalination as incurring very similar costs. Energy is the determining factor in the economics of different source waters, with the specific energy consumption for surface, brackish or wastewater being 0.4$1.0 \mathrm{kWh} / \mathrm{m} 3$, versus that of seawater at $3-3.4 \mathrm{kWh} / \mathrm{m} 3$.

In summary, reuse is more energy efficient than seawater desalination. This has a significant impact on $\mathrm{CO} 2$ emissions, and consequently, on the global environment. energy and associated $\mathrm{CO} 2$ emissions, variation of environmental flows and wastewater discharge, with associated impacts on habitats and biodiversity. Natural 
1 water bodies, such as rivers, lakes, groundwater and wetlands, are often affected.

2 While water recycling produces clean water, it also often involves cleaning up wastewater which might be discharged into the environment without adequate treatment, causing a range of environmental problems (Beder, 1989; Ternes et al., 1999; Braga et al., 2005; Dawoud, 2005; Sumpter, 2005). Such discharge may also contaminate drinking water (Heberer, 2002). The environmental impacts resulting from water recycling and desalination can be summarized in the following categories: energy consumption, waste production, and other impacts.

Energy consumption and related greenhouse gas emissions, as well as air pollution due to desalination, are high for water recycling and desalination. These need to be reduced, particularly for seawater desalination. Meerganz von Medeazza (2005) suggests a reduction of environmental impacts by a target energy consumption for water production (including transport) at $3 \mathrm{kWh} / \mathrm{m} 3$. Environmental impacts depend on the energy source, and are usually associated with significant airborne emissions (Alameddine and El-Fadel, 2005; Meerganz von Medeazza, 2005). However, the desalination approach risks shifting the focus from water to energy. Raluy et al. (2006) suggest coupling desalination with renewable energies, because the environmental impact of desalination plants is dominated by energy.

Waste production and discharge/treatment (such as cleaning effluents and brines/concentrates) affect both the economics and the environmental impact of 21 desalination (Lattemann, 2003; Lattemann and Höpner, 2007; Lattemann, Submitted). 22 The concentrate produced in reverse osmosis is a substantial portion of the treated water, and contains a concentrated amount of the salt and other contaminants retained by the process. The high salt concentration of brines in seawater desalination can destroy large areas of ocean floor, due to the high density of such wastes (Einav, Harussi et al. 2002; Meerganz von Medeazza 2005). Discharge of iron can also cause significant discolouration of the ocean floor (Einav and Lokiec, 2003), and several desalination plants situated in one region can cause severe regional impacts (Lattemann and Höpner, 2007).

The effects of brine discharge are worsened by chemicals added as antifouling agents, coagulants, disinfectants, $\mathrm{pH}$ adjustments and specific compounds, such as heavy metals (Meerganz von Medeazza, 2005). These compounds are released with as-yet-unknown impacts. 
Land use, noise, visual impact and disturbance of recreation areas are other environmental impacts on a local scale. Broader environmental issues include groundwater intrusion, soil salinity, deteriorated catchments, and the spread of invasive species (Lake and Bond, 2006). Lake and Bond (2006) predict that if business continues as usual, restoration and conservation efforts "will struggle to keep pace with the degradation generated by past legacies, and by continued pressure from resource development."

\section{Data and Methodology}

The fieldwork for this study was conducted using an Australian permissionbased Internet panel. This panel maintains a respondent database that is representative of the Australian population based on the Australian Bureau of Statistic's (ABS) census information. Respondents were randomly selected from this panel, were invited to complete a 30-minute questionnaire online, and received a monetary compensation for completing it. Such compensation is a standard payment that is prescribed by the panel company, and depends on the duration of the questionnaire. The invitation to participate was closed when 1,000 respondents completed the survey. No follow-up invitations were needed to obtain the required 1,000 respondents.

In order to assess potential response bias, the sample was compared to the 2001 Census data provided by the Australian Bureau of Statistics. This comparison confirmed that the random selection procedure based on a representative panel produced a sample that was representative of the Australian population with respect to basic socio-demographic variables. Only the age group of respondents between 55 and 64 was slightly overrepresented in our sample (seven percent of those aged 55-59 according to the Census, compared to 16 percent in the sample; six percent of those aged 60-64 in the Census, compared to 11 percent in the sample). Sample representatively is particularly important for all results in which population percentages are reported; the profiling analysis does not require a representative sample because the aim is to study an extreme population group, not the entire population. 
The questionnaire contained the questions below, which allow comparisons between the public perception and acceptance of recycled and desalinated water:

(1) A perceptions/knowledge question, in which respondents were asked to state whether or not each of a list of statements was true for recycled and desalinated water separately. The hypothesis underlying these items was that the general knowledge level about alternative water sources among the Australian population was low, and as a consequence, people held erroneous beliefs about recycled and desalinated water. The authors developed the items to capture both the level of factual knowledge and water-related perceptions. However, it was not a priori clear if all the terms used could be included in the survey (particularly terms used in the knowledge questions). Therefore the questionnaire was pre-tested for relevance and understanding using a sample of 10 adult respondents. They were presented with the questionnaire in written form and asked to comment while they were completing the survey. No major problems occurred, but a few items were slightly reworded, and some layout changes were made in order to draw attention to essential instructions. The full instructions and the items are provided in the Appendix.

(2) A stated likelihood of use question, in which respondents were asked to state on a five-point scale how likely they were to use recycled/desalinated water for a list of purposes. The researchers adopted this question format because it has been used successfully in most prior studies in which stated acceptance levels were measured empirically (Bruvold and Ward, 1970; Bruvold, 1972; Kasperson et al., 1974; Sims and Baumann, 1974; Stone and Kahle, 1974; Olson et al., 1979; Bruvold et al., 1981; Milliken and Lohman, 1985; Po et al., 2004).

In order to avoid bias arising from respondents who assumed different treatment procedures, respondents were given the following instructions for answering the question: "For the following questions we will use the term 'recycled water' to describe 'purified wastewater or sewage,' and we will use the term 'desalinated water' to describe 'purified seawater,' and we will assume that both recycled and desalinated water are treated to the same level of water quality." We deliberately included this information after the perception/knowledge question, which

31 assessed the general public's perception of both alternative water sources without additional information. The full instructions and items are provided in the Appendix. 
(3) A ranking question, in which respondents were asked to rank uses of water

2 separately for recycled and desalinated water, indicating in which order they would adopt the purposes. This is a novel approach to measuring the stated willingness to use alternative water sources, and was included in order to confront respondents with a trade-off situation where they were asked to declare their preferences regarding which uses they would be willing to use desalinated/recycled water sources.

(4) An open-ended question, asking respondents to state their primary concerns with using each water source. This was included to determine reasons for resistance to using recycled and desalinated water.

In addition, several socio-demographic and behavioural variables were included in the survey: age, gender, education, occupation, and media usage.

While the study contains new elements which have not been investigated previously (knowledge/perceptions about water types in comparison to each other, ranking of uses, and so on) some of the limitations of traditional public acceptance studies also apply to our study (Baumann, 1983; Alhumoud et al., 2003; Comrie et $a l ., 2003)$. For example, the questions about the likelihood of adoption are hypothetical, given that most of the respondents have had no prior experience with either recycled or desalinated water. Also, appearance and smell could not be included in the written online fieldwork as evaluation criteria for their likelihood of use. Neither does this study assume that the perceptions identified are stable, or can be generalized beyond Australia (Russell, 2004).

Very few Australians have had personal experiences with alternative water sources, yet recycled water and desalinated water schemes have received wide public attention in Australia for many years because of continued severe and widespread drought conditions. Seventy percent of respondents in our sample stated that they made a small, big or even huge effort to "look for information on water-related issues (for example, water recycling, desalination, water conservation, rain water and so on);" 94 percent stated that they had experienced water restrictions and 89 percent stated that they "had to change [their] behavior because of water restrictions."

Although we assumed that respondents had formed opinions about alternative 31 water sources, very few would have done so on the basis of personal experience. Their perceptions of alternative water sources were essentially a "brand image" 
1 problem at the time of research. The perceptions/knowledge items in the survey represent items typical of brand image studies. Items were derived from prior studies and interviews with Australian residents, they were pre-tested to ensure understanding and non-redundancy, and presented for evaluation to respondents to enable a comparative image assessment of recycled versus desalinated water.

It should also be noted at this point that Australian do not have a direct choice to use or not to use recycled or desalinated water. Dual reticulation systems would have to be installed for consumers to have the actual choice at household level, which is not possible for individual household but only at the level of residential developments. Consequently increasing the acceptance levels for alternative water sources at this state of development of alternative water sources in Australia is not expected to lead to instant behavioral changes. Instead, high public acceptance level are essential to make the construction of new recycling and desalination plants which will have consequences for household water supplies politically viable.

Analyses of variance were used to test for differences in metric variables; chisquared tests were applied where participants' responses to a nominal answer format were compared; and t-tests for proportions were used to test differences in population percentages.

\section{Results and Discussion}

\section{Main concerns raised by respondents}

The open-ended question in which respondents were asked to state their main concerns with recycled and desalinated water centered on three main themes: health concerns, environmental concerns, and cost. Recycled water was perceived as more risky from a health perspective (55 percent of respondents listed health-related concerns in the open-ended question). Desalinated water was primarily perceived as bad for the environment (12 percent, and only 23 percent mentioned health-related concerns), but it was also viewed as the more expensive alternative, with 11 percent mentioning a cost-related concern. This confirms earlier findings by Bruvold (1988),

30 Dishman et al. (1989), Higgins et al. (2002) and Marks et al. (2002).

$31 \quad$ Perceptions and knowledge about alternative water sources 
Results derived from the open-ended question do not permit direct comparisons between recycled and desalinated water, because respondents were free to express whatever they wanted. We therefore used the set of questions in which respondents were asked to evaluate their perceptions/knowledge about recycled and desalinated water to determine this issue. Figure 1 provides the comparison of items related to environmental issues, sorted in descending order for recycled water.

The responses to the open-ended questions are very similar: respondents perceived recycled water (dark gray columns) as more environmentally friendly, and they were aware that desalination (white columns) produced higher levels of greenhouse emissions and required more energy. However, 46 percent of respondents stated that desalinated water was environmentally responsible. More respondents believed that desalination could be of environmental concern than did for recycled water. Recycled water was most frequently perceived as the most environmentally friendly source of water, and was seen to contribute to reducing the contamination of beaches.

T-tests for proportions were computed to assess whether the visually detected differences were statistically significant. With respect to two items ("can save Australia from drought" and "reduces the need for water restrictions"), respondents did not perceive a difference between recycled and desalinated water. Figure 1 includes comparative values for tap water and bottled water. Both recycled and desalinated water were generally evaluated as more environmentally friendly than both tap and bottled water. We assume that the reason for this perception is that Australians are very aware of the drought and the serious lack of fresh water resources, and consequently believe that alternative water sources are good for the environment because they take the pressure off natural resources.

Bottled water was perceived as the second-most environmentally unfriendly source of water, and a large proportion of respondents believed that it used a lot of energy in production, that it produced greenhouse emissions and that it could be of environmental concern. With respect to producing high levels of greenhouse emissions and using a lot of energy, tap water was rated better than both alternative water sources. These perceptions may indicate several differences between the four water sources evaluated which could be used for targeted public information campaigns. 
Figure 2 provides the answers to the health-related items. Sixty-nine percent of respondents believed that desalinated water was healthy, compared to only 46 percent who believed that recycled water was healthy. With respect to all health-related questions, respondents felt that desalinated water was the safer choice. The level of trust indicated towards providers of both recycled and desalinated water was similar, and high, with more than two-thirds expressing their confidence in the water providers.

Despite these results, the lack of knowledge in the population is illustrated by the responses to the knowledge questions, shown in Figures 1 and 2. For instance, 24 percent of respondents agreed that desalinated water is purified sewage; and 20 percent believed that chemicals such as endocrine disruptors are present in desalinated water. Both these statements are incorrect. Differences between attitudes towards desalinated and recycled water regarding the health-related items are highly significant at the 99 percent level, except for the perception that water quality can be affected during transport.

The comparisons with the tap and bottled water (benchmarks) show that, in terms of health, respondents perceived both recycled and desalinated water as inferior to currently available water sources. However, tap water was ranked worst in terms of containing chemicals, with 94 percent of all respondents agreeing with this statement. This compares with only 81 percent of respondents agreeing that recycled water contained chemicals. This perception could offer an opportunity for marketers to position alternative water sources as having a competitive advantage over presently available supplies.

[Figure 2]

The questionnaire included several other, less knowledge-oriented questions,

31 and their responses are provided in Figure 3. The results indicate that the population's 
1 reservations about recycled water were more firmly held than those towards

2 desalinated water. For example, 79 percent of respondents perceived desalinated

3 water as drinkable; only half classified recycled water as such. Sixty-one percent had

4 health concerns about drinking recycled water; only 33 percent had those concerns

5 regarding desalinated water. Even with respect to clarity and odor, respondents

6 perceived desalinated water to be superior to recycled water. Respondents further

7 believed that recycled water contains more chemicals (such as disinfectants) as well

8 as microorganisms. However, they did acknowledge one disadvantage: the higher cost

9 associated with desalinated water in the production process, and consequently for the 10 consumer.

11 All the variables in Figure 3 (except creating new jobs) differ significantly for 12 recycled and desalinated water.

Both bottled and tap water elicited more favourable evaluations from

14 respondents than desalinated and recycled water, regarding drinkability. Bottled water

15 was perceived as the most clear and odorless water option, but respondents

16 acknowledged that it also represented the most expensive source of water for the consumer. Tap water was perceived as the cheapest option, but was evaluated as clear and odorless by fewer people than was desalinated water. This supports the image of Australians which emerged in the context of health evaluation questions: that tap water is perceived as having several negative aspects. This perception may indicate very favorable conditions for the introduction of alternative water sources.

[Figure 3]

$\underline{\text { Stated likelihood of use }}$

The above results lead to the hypothesis that stated acceptance levels of recycled water will be lower than stated acceptance levels of desalinated water. In order to assess this statement, the questions about the stated likelihood of use were analyzed. Figure 4 contains the proportion of respondents who indicated that it was either "very likely" or "rather likely" that they would use recycled water and

31 desalinated water, respectively, for each of the listed water uses. Desalinated water 32 was unlikely to be preferred for use over recycled water for all uses. For water uses 
1 that involve human contact, desalinated water was "very likely" to be used by a larger proportion of the population. For uses not close to the body (such as watering the garden) recycled water was "very likely" to be used by a larger proportion of Australians.

A step up in stated likelihood was observed for recycled water from garden watering to clothes washing, while the decrease in stated likelihood is steadier for desalinated water. The lower stated likelihood of using desalinated water for low body contact applications may reflect some respondents' knowledge that such high quality water is not required for those applications. At the high body contact end of the spectrum, this result turns, and desalinated water was preferred by approximately 10 30 percent more respondents than recycled water.

Different alternative water sources attract different segments of water users. Except for the item "washing the house, windows, driveways," all the differences in stated likelihood of use between recycled and desalinated water are highly statistically significant ( $\mathrm{p}$-values $<0.001$, meaning that the stated likelihood that such differences

While this finding is important, and can be directly compared to prior work that studies stated acceptance levels or stated likelihood of use, the question format of the likelihood question does not put respondents into a situation of trade-off. Theoretically, they might have stated that they would not use recycled or desalinated water for any use. However, the above findings are validated by studying the ranking question, in which respondents indicated in which order they would adopt recycled or desalinated water for different uses. To avoid purely hypothetical questions, the ranking question was formulated as a scenario. The following instructions were given to respondents: "Please imagine (1) that water levels drop to a critical level at which tap water supply is insufficient to cover the populations' household water requirements, (2) that you do not have a rainwater tank or any other source of water, and (3) that tap water prices triple (increase by 300 percent), but recycled water and desalinated water are available at the current (low) tap water price. Please number the 
1 following uses from 1 to 18 in the order in which you would be willing to replace tap

2 water with recycled/desalinated water. Please use the value ' 1 ' for the first thing you

3 would switch to recycled/desalinated water." This question format forced respondents

4 to compare water uses (a trade-off situation) and state the order of adoption of

5 recycled and desalinated water. Figure 5 provides the results.

While the absolute order of ranking shows the typical pattern of close-to-body uses being adopted last, the conclusions drawn from the expressed willingness to use question are supported by the ranking task. Items such as watering the garden, irrigation of parks, and toilet flushing were stated to be adopted earlier in the case of recycled water. Uses such as refilling the swimming pool, cooking and drinking were stated to be adopted earlier in the case of desalinated water. The pattern shown in Figure 5 illustrates that the order of stated adoption of alternative water uses was influenced more strongly by the actual use than it was by the source of alternative 14 water.

[Figure 5]

\section{$\underline{\text { Strong Accepter Profile }}$}

Strong accepters among residents are a very useful segment for starting a diffusion process of public acceptance for alternative water sources. Hanke and Athanasiou (1970) propose the introduction of recycled water in high-status communities first, a recommendation based on findings that socio-demographic characteristics of the population are associated with acceptance rates. The more distinct the profile of such a strong accepter segment, the better for marketing purposes, because the segments are known to exist and can be easily reached through communication channels.

This study does not contain behavioural information, so cannot be used to identify individuals who have actually adopted alternative water sources first. Based on the differences in expressed adoption likelihoods, we can, however, profile respondents who are the most open-minded with respect to using alternative water

31 schemes. This group of respondents will be referred to as "strong accepters." 
In order to identify the strong accepters for recycled and desalinated water in

2 Australia, a summated score across all stated likelihood of use items was computed.

3 Respondents within the top third were classified as being the most open to the use of

4 alternative water sources. Their profiles were compared to the other respondents to

5 assess whether distinct and marketable strong accepters can be identified.

To test the hypothesis whether strong accepters of recycled water overlap strongly with strong accepters of desalinated water, a cross-tabulation of membership was constructed and a chi-squared test computed. The highly significant test results produced an unexpected result: the two strong accepter groups are quite distinctly separate groups of people. Twenty percent of all respondents are classified as "general strong accepters" for both recycled and desalinated water; 15 percent as "early desalination adopters;" and 19 percent as "early recycling adopters." This necessitated profiling of the three strong accepter segments separately with respect to sociodemographic characteristics. These emerged in prior work as being associated with the acceptance of recycled water. Table 1 shows the profiles for all three strong accepter segments, as well as the contrast group of all other respondents. The percentages in the table represent the proportion of each segment that gave a specific answer. Where a number is given instead of a percentage, the dependent variable was metric in nature, and the number represents the average within each segment. The pvalues in the last column are based on either chi-squared tests (when the dependent variable was nominal or ordinal) or analyses of variance (when the dependent variables were metric).

\section{[Table 1]}

Table 1 indicates that all strong accepters are significantly older than other respondents. These findings confirm the results of Sims and Baumann (1974), but contradict findings from Hurliman and McKay (2003) in the Australian context, and from Hanke and Athanasiou (1970).

Across all strong accepter groups, the proportion of men was higher than of 31 women. These findings align with socio-demographic profiles reported by Olsen et al. 32 (1979) for the US, and Hurliman and McKay (2003) for Australia. However, they 
1 contradict the conclusions drawn by Sims and Baumann (1974), Hanke and

2 Athanasiou (1970), and Johnson (1979): that gender is not associated with the

3 acceptance of recycled water.

Regarding education level, the proportion of strong accepters who had only completed secondary school was significantly lower than among other respondents in the present study. This aligns with the findings of all other studies that included education as a personal characteristic in their empirical studies (Hanke and Athanasiou, 1970; Olson et al., 1979; Alhumoud et al., 2003; Hurliman and McKay, 2003) strong accepters" and "desalinated water strong accepters;" whereas more managers and administrators were among "recycled water strong accepters." These three subsegments of the strong accepter segment are named to indicate the kind of alternative water source that they are more likely than the general population to use at an earlier stage. For the "general strong accepters" this was the case for both recycled and desalinated water. No prior studies include this descriptor.

Media behavior is an important profiling variable used to develop optimal communication strategies with these segments. "General" and "recycled water strong accepters" watch state-run TV channels (ABC and SBS) more frequently than do the other two segments, which make more use of one particular commercial TV Channel, Win. Other channels (cable) are most used by non-strong accepters. The proportion of newspaper readers is higher among all strong accepter groups, which invites the conclusion that the more-informed respondents were more open towards water reuse and/or desalination.

Respondents were also asked how they would react if they had to switch their entire household water supply to either recycled or desalinated water. Responses to these two questions highlighted that "recycled water early adaptors" and "desalinated water early adaptors" represent two quite distinct market segments with very strong views about these alternative water sources. Significantly more (46 percent) of the "desalinated water strong accepters" state that they would not switch their entire

31 household to recycled water under any circumstances; whereas only 33 percent of the non-early adaptors reacted as strongly. Responses to the question about switching to 
1 desalinated water produced a proportion of refusers approximately equal among

2 "recycling water strong accepters" and others. The stated willingness to pay the same

3 or even a higher price for water under this scenario was highest among "general

4 strong accepters" and "water recycling strong accepters."

$5 \quad$ No differences were evident between the prior experience of respondents with 6 water restrictions and their feeling of being limited by these measures. No differences 7 in income, state of residence, size of the city of residence, frequency of watching TV 8 and number of years lived in Australia were detected as influences on responses.

9 


\section{Conclusions}

The Australian population discriminates between recycled and desalinated water. Although responses to the knowledge questions reveal gaps in the population's general level of knowledge, respondents understand that recycled water is the more environmentally friendly option, whereas desalinated water is perceived as less risky from a public health point of view. Responses to emotional items such as "is disgusting" indicate that Australians currently have fewer reservations about desalinated water than recycled water, despite the fact that identical water quality is assumed. This is supported by responses to the question about the stated likelihood of adoption of both kinds of water, where the stated likelihood for close-to-body uses was higher for desalinated water.

The results also indicate that we cannot state that Australians generally perceive as preferable either desalinated water or recycled water. Australians discriminate according to water use. Their stated likelihood of adoption for close-tobody purposes is comparatively high for desalinated water, compared with irrigation, cleaning the car, and house maintenance, for which recycled water is ranked higher in the adoption sequence.

The results have implications for water policy makers and managers. The order of stated adoption of alternative water sources for different household uses is the same for both types of water, and is determined by closeness to body. This supports prior recommendations made by water recycling researchers. Baumann and Kasperson (1974) suggest that a successful strategy should associate the water reuse program with pleasant activities the public enjoys and approves, for instance, to "put the reclaimed water in an attractive setting and invite the public to look at it, sniff it, picnic around it, fish in it, and swim in it" (p. 670). Studies conducted by Bruvold and Ward (1970) and Bruvold (1972) found that opposition to recycled water dropped significantly after swimming in it.

Results also indicate that Australians are mainly concerned about health issues that may be related to using water from alternative sources in their households while at the same time having only a low level of factual knowledge about the true health risks associated with desalinated and recycled water. Another practical consequence consequently is to try to fill the public knowledge gap through a range of possible 
1 channels, including education in schools, public information campaigns, public consultations in regions where desalination and recycling plants are planned etc.

The contrast perceived between recycled/desalinated water and tap/bottled

4 water indicates potential for targeted communication messages by public campaigns,

5 for example, that recycled/desalinated water is cheap, creates new jobs for

6 Australians, and uses fewer chemicals. work should investigate whether personal characteristics, such as the education level,

9 prior experience with recycled or desalinated water, prior experience with drought, 10 and so on, affect knowledge, perception and likelihood of use. In particular, studies of 11 actual behavior and actual behavior change should provide valuable new insights and 12 may resolve some of the contradictory findings resulting from prior studies.

Additional research directions could investigate in more detail how the current

14 perceptions of recycled and desalinated water were formed. This would require

15 qualitative research methods and could use the perceptions/knowledge items

16 developed for the present study as a starting point.

Acknowledgments

This project was supported by the Australian Research Council under Discovery Grant DP0557769 and the International Science Linkages program established under the Australian Government's innovation statement Backing

22 Australia's Ability. It is funded by the Commonwealth Department of Education

23 Science and Training for the project OzAquarec: Integrated Concepts for Reuse of 24 Upgraded Wastewater in Australia (CG030025). 


\section{Appendix - Survey items}

\section{$2 \quad$ Perceptions/knowledge items}

3 You will now see a list of descriptions of water. Please indicate whether or not you

4 think that each of the descriptions applies to the four kinds of water listed on top:

5 recycled water, desalinated water, tap water and bottled water by either ticking the

6 YES or the NO button. If you are not sure, please tick the option you think is more

7 likely.

\begin{tabular}{|c|c|c|c|c|}
\hline & $\begin{array}{l}\text { Recycled } \\
\text { water }\end{array}$ & $\begin{array}{l}\text { Desalinated } \\
\text { water }\end{array}$ & Tap water & $\begin{array}{l}\text { Bottled } \\
\text { water }\end{array}$ \\
\hline $\begin{array}{l}\text { Contains chemicals, such as } \\
\text { chlorine }\end{array}$ & $\begin{array}{l}\square \text { Yes [1] } \\
\square \text { No [0] }\end{array}$ & $\begin{array}{l}\square \text { Yes [1] } \\
\square \text { No [0] }\end{array}$ & $\begin{array}{l}\square \text { Yes [1] } \\
\square \text { No [0] }\end{array}$ & $\begin{array}{l}\square \text { Yes [1] } \\
\square \text { No [0] }\end{array}$ \\
\hline Is purified sewage & $\begin{array}{l}\square \text { Yes [1] } \\
\square \text { No [0] }\end{array}$ & $\begin{array}{l}\square \text { Yes [1] } \\
\square \text { No [0] }\end{array}$ & $\begin{array}{l}\square \text { Yes [1] } \\
\square \text { No [0] }\end{array}$ & $\begin{array}{l}\square \text { Yes [1] } \\
\square \text { No [0] }\end{array}$ \\
\hline $\begin{array}{l}\text { Producing it could be an } \\
\text { environmental concern }\end{array}$ & $\begin{array}{l}\square \text { Yes [1] } \\
\square \text { No [0] }\end{array}$ & $\begin{array}{l}\square \text { Yes [1] } \\
\square \text { No [0] }\end{array}$ & $\begin{array}{l}\square \text { Yes [1] } \\
\square \text { No [0] }\end{array}$ & $\begin{array}{l}\square \text { Yes [1] } \\
\square \text { No [0] }\end{array}$ \\
\hline Is drinkable & $\begin{array}{l}\square \text { Yes [1] } \\
\square \text { No [0] }\end{array}$ & $\begin{array}{l}\square \text { Yes [1] } \\
\square \text { No [0] }\end{array}$ & $\begin{array}{l}\square \text { Yes [1] } \\
\square \text { No [0] }\end{array}$ & $\begin{array}{l}\square \text { Yes [1] } \\
\square \text { No [0] }\end{array}$ \\
\hline $\begin{array}{l}\text { Using it reduces the amount of } \\
\text { wastewater discharged to the } \\
\text { environment }\end{array}$ & $\begin{array}{l}\square \text { Yes [1] } \\
\square \text { No [0] }\end{array}$ & $\begin{array}{l}\square \text { Yes [1] } \\
\square \text { No [0] }\end{array}$ & $\begin{array}{l}\square \text { Yes [1] } \\
\square \text { No [0] }\end{array}$ & $\begin{array}{l}\square \text { Yes [1] } \\
\square \text { No [0] }\end{array}$ \\
\hline $\begin{array}{l}\text { Could be a health concern, for } \\
\text { instance if people would drink it. }\end{array}$ & $\begin{array}{l}\square \text { Yes [1] } \\
\square \text { No [0] }\end{array}$ & $\begin{array}{l}\square \text { Yes [1] } \\
\square \text { No [0] }\end{array}$ & $\begin{array}{l}\square \text { Yes [1] } \\
\square \text { No [0] }\end{array}$ & $\begin{array}{l}\square \text { Yes [1] } \\
\square \text { No [0] }\end{array}$ \\
\hline $\begin{array}{l}\text { Quality can be affected by the way } \\
\text { it is transported to your home }\end{array}$ & $\begin{array}{l}\square \text { Yes [1] } \\
\square \text { No [0] }\end{array}$ & $\begin{array}{l}\square \text { Yes [1] } \\
\square \text { No [0] }\end{array}$ & $\begin{array}{l}\square \text { Yes [1] } \\
\square \text { No [0] }\end{array}$ & $\begin{array}{l}\square \text { Yes [1] } \\
\square \text { No [0] }\end{array}$ \\
\hline Is expensive for the consumer & $\begin{array}{l}\square \text { Yes [1] } \\
\square \text { No [0] }\end{array}$ & $\begin{array}{l}\square \text { Yes [1] } \\
\square \text { No [0] }\end{array}$ & $\begin{array}{l}\square \text { Yes [1] } \\
\square \text { No [0] }\end{array}$ & $\begin{array}{l}\square \text { Yes }[1] \\
\square \text { No }[0]\end{array}$ \\
\hline Contains bacteria or viruses & $\begin{array}{l}\square \text { Yes [1] } \\
\square \text { No [0] }\end{array}$ & $\begin{array}{l}\square \text { Yes [1] } \\
\square \text { No [0] }\end{array}$ & $\begin{array}{l}\square \text { Yes [1] } \\
\square \text { No [0] }\end{array}$ & $\begin{array}{l}\square \text { Yes }[1] \\
\square \text { No }[0]\end{array}$ \\
\hline Uses a lot of energy in production & $\begin{array}{l}\square \text { Yes [1] } \\
\square \text { No [0] }\end{array}$ & $\begin{array}{l}\square \text { Yes [1] } \\
\square \text { No [0] }\end{array}$ & $\begin{array}{l}\square \text { Yes [1] } \\
\square \text { No [0] }\end{array}$ & $\begin{array}{l}\square \text { Yes [1] } \\
\square \text { No [0] }\end{array}$ \\
\hline $\begin{array}{l}\text { Contains substances such as } \\
\text { hormones or endocrine disruptors } \\
\text { which can affect human fertility }\end{array}$ & $\begin{array}{l}\square \text { Yes [1] } \\
\square \text { No [0] }\end{array}$ & $\begin{array}{l}\square \text { Yes [1] } \\
\square \text { No [0] }\end{array}$ & $\begin{array}{l}\square \text { Yes [1] } \\
\square \text { No [0] }\end{array}$ & $\begin{array}{l}\square \text { Yes }[1] \\
\square \text { No }[0]\end{array}$ \\
\hline $\begin{array}{l}\text { Increases the amount of available } \\
\text { freshwater }\end{array}$ & $\begin{array}{l}\square \text { Yes [1] } \\
\square \text { No [0] }\end{array}$ & $\begin{array}{l}\square \text { Yes [1] } \\
\square \text { No [0] }\end{array}$ & $\begin{array}{l}\square \text { Yes [1] } \\
\square \text { No [0] }\end{array}$ & $\begin{array}{l}\square \text { Yes [1] } \\
\square \text { No [0] }\end{array}$ \\
\hline Can save Australia from drought & $\begin{array}{l}\square \text { Yes [1] } \\
\square \text { No [0] }\end{array}$ & $\begin{array}{l}\square \text { Yes [1] } \\
\square \text { No [0] }\end{array}$ & $\begin{array}{l}\square \text { Yes [1] } \\
\square \text { No [0] } \\
\end{array}$ & $\begin{array}{l}\square \text { Yes }[1] \\
\square \text { No }[0]\end{array}$ \\
\hline Is expensive to produce & $\begin{array}{l}\square \text { Yes [1] } \\
\square \text { No [0] }\end{array}$ & $\begin{array}{l}\square \text { Yes [1] } \\
\square \text { No [0] }\end{array}$ & $\begin{array}{l}\square \text { Yes [1] } \\
\square \text { No [0] }\end{array}$ & $\begin{array}{l}\square \text { Yes }[1] \\
\square \text { No }[0]\end{array}$ \\
\hline $\begin{array}{l}\text { Reduces the need for water } \\
\text { restrictions }\end{array}$ & $\begin{array}{l}\square \text { Yes [1] } \\
\square \text { No [0] }\end{array}$ & $\begin{array}{l}\square \text { Yes [1] } \\
\square \text { No [0] }\end{array}$ & $\begin{array}{l}\square \text { Yes [1] } \\
\square \text { No [0] }\end{array}$ & $\begin{array}{l}\square \text { Yes [1] } \\
\square \text { No [0] }\end{array}$ \\
\hline Requires chemicals to be produced & $\begin{array}{l}\square \text { Yes [1] } \\
\square \text { No [0] }\end{array}$ & $\begin{array}{l}\square \text { Yes [1] } \\
\square \text { No [0] }\end{array}$ & $\begin{array}{l}\square \text { Yes [1] } \\
\square \text { No [0] } \\
\end{array}$ & $\begin{array}{l}\square \text { Yes [1] } \\
\square \text { No [0] }\end{array}$ \\
\hline Produces greenhouse emissions & $\begin{array}{l}\square \text { Yes [1] } \\
\square \text { No [0] }\end{array}$ & $\begin{array}{l}\square \text { Yes [1] } \\
\square \text { No [0] }\end{array}$ & $\begin{array}{l}\square \text { Yes [1] } \\
\square \text { No [0] }\end{array}$ & $\begin{array}{l}\square \text { Yes [1] } \\
\square \text { No [0] }\end{array}$ \\
\hline Is environmentally responsible & $\begin{array}{l}\square \text { Yes [1] } \\
\square \text { No [0] }\end{array}$ & $\begin{array}{l}\square \text { Yes [1] } \\
\square \text { No [0] }\end{array}$ & $\begin{array}{l}\square \text { Yes [1] } \\
\square \text { No [0] }\end{array}$ & $\begin{array}{l}\square \text { Yes [1] } \\
\square \text { No [0] }\end{array}$ \\
\hline Is odourless & $\begin{array}{l}\square \text { Yes [1] } \\
\square \text { No [0] }\end{array}$ & $\begin{array}{l}\square \text { Yes [1] } \\
\square \text { No [0] }\end{array}$ & $\begin{array}{l}\square \text { Yes [1] } \\
\square \text { No [0] }\end{array}$ & $\begin{array}{l}\square \text { Yes [1] } \\
\square \text { No [0] }\end{array}$ \\
\hline $\begin{array}{l}\text { Is the most environmentally } \\
\text { responsible water source to use }\end{array}$ & $\begin{array}{l}\square \text { Yes [1] } \\
\square \text { No [0] }\end{array}$ & $\begin{array}{l}\square \text { Yes [1] } \\
\square \text { No [0] }\end{array}$ & $\begin{array}{l}\square \text { Yes [1] } \\
\square \text { No [0] }\end{array}$ & $\begin{array}{l}\square \text { Yes [1] } \\
\square \text { No [0] }\end{array}$ \\
\hline Is healthy & $\square$ Yes [1] & $\square$ Yes [1] & $\square$ Yes [1] & $\square$ Yes $[1]$ \\
\hline
\end{tabular}




\begin{tabular}{|c|c|c|c|c|}
\hline & $\begin{array}{l}\text { Recycled } \\
\text { water }\end{array}$ & $\begin{array}{l}\text { Desalinated } \\
\text { water }\end{array}$ & Tap water & $\begin{array}{l}\text { Bottled } \\
\text { water }\end{array}$ \\
\hline & $\square$ No $[0]$ & $\mathrm{No}[0]$ & $\square$ No $[0]$ & $\square$ No $[0]$ \\
\hline $\begin{array}{l}\text { Is the most responsible water source } \\
\text { to use from a public health } \\
\text { perspective }\end{array}$ & $\begin{array}{l}\square \text { Yes [1] } \\
\square \text { No [0] }\end{array}$ & $\begin{array}{l}\square \text { Yes [1] } \\
\square \text { No [0] }\end{array}$ & $\begin{array}{l}\square \text { Yes [1] } \\
\square \text { No [0] }\end{array}$ & $\begin{array}{l}\square \text { Yes [1] } \\
\square \text { No [0] }\end{array}$ \\
\hline Is prone to technology failure & $\begin{array}{l}\square \text { Yes [1] } \\
\square \text { No [0] }\end{array}$ & $\begin{array}{l}\square \text { Yes [1] } \\
\square \text { No [0] }\end{array}$ & $\begin{array}{l}\square \text { Yes [1] } \\
\square \text { No [0] }\end{array}$ & $\begin{array}{l}\square \text { Yes [1] } \\
\square \text { No [0] }\end{array}$ \\
\hline $\begin{array}{l}\text { Because the water cycle is closed, it } \\
\text { contains human waste }\end{array}$ & $\begin{array}{l}\square \text { Yes [1] } \\
\square \text { No [0] }\end{array}$ & $\begin{array}{l}\square \text { Yes [1] } \\
\square \text { No [0] }\end{array}$ & $\begin{array}{l}\square \text { Yes [1] } \\
\square \text { No [0] }\end{array}$ & $\begin{array}{l}\square \text { Yes [1] } \\
\square \text { No [0] }\end{array}$ \\
\hline Looks absolutely clear & $\begin{array}{l}\square \text { Yes [1] } \\
\square \text { No [0] }\end{array}$ & $\begin{array}{l}\square \text { Yes [1] } \\
\square \text { No [0] }\end{array}$ & $\begin{array}{l}\square \text { Yes [1] } \\
\square \text { No [0] } \\
\end{array}$ & $\begin{array}{l}\square \text { Yes }[1] \\
\square \text { No }[0]\end{array}$ \\
\hline $\begin{array}{l}\text { I trust the provider that the quality is } \\
\text { suitable for the intended usage }\end{array}$ & $\begin{array}{l}\square \text { Yes [1] } \\
\square \text { No [0] }\end{array}$ & $\begin{array}{l}\square \text { Yes [1] } \\
\square \text { No [0] }\end{array}$ & $\begin{array}{l}\square \text { Yes [1] } \\
\square \text { No [0] }\end{array}$ & $\begin{array}{l}\square \text { Yes [1] } \\
\square \text { No [0] }\end{array}$ \\
\hline Stains the washing & $\begin{array}{l}\square \text { Yes [1] } \\
\square \text { No [0] }\end{array}$ & $\begin{array}{l}\square \text { Yes [1] } \\
\square \text { No [0] }\end{array}$ & $\begin{array}{l}\square \text { Yes [1] } \\
\square \text { No [0] } \\
\end{array}$ & $\begin{array}{l}\square \text { Yes }[1] \\
\square \mathrm{No}[0]\end{array}$ \\
\hline Is disgusting & $\begin{array}{l}\square \text { Yes [1] } \\
\square \text { No [0] }\end{array}$ & $\begin{array}{l}\square \text { Yes [1] } \\
\square \text { No [0] }\end{array}$ & $\begin{array}{l}\square \text { Yes [1] } \\
\square \text { No [0] }\end{array}$ & $\begin{array}{l}\square \text { Yes [1] } \\
\square \text { No [0] }\end{array}$ \\
\hline Creates new jobs & $\begin{array}{l}\square \text { Yes [1] } \\
\square \text { No [0] }\end{array}$ & $\begin{array}{l}\square \text { Yes [1] } \\
\square \text { No [0] }\end{array}$ & $\begin{array}{l}\square \text { Yes [1] } \\
\square \text { No [0] }\end{array}$ & $\begin{array}{l}\square \text { Yes [1] } \\
\square \text { No [0] }\end{array}$ \\
\hline Reduces contamination of beaches & $\begin{array}{l}\square \text { Yes [1] } \\
\square \text { No [0] }\end{array}$ & $\begin{array}{l}\square \text { Yes [1] } \\
\square \text { No [0] }\end{array}$ & $\begin{array}{l}\square \text { Yes [1] } \\
\square \text { No [0] }\end{array}$ & $\begin{array}{l}\square \text { Yes [1] } \\
\square \text { No [0] }\end{array}$ \\
\hline
\end{tabular}

\section{$2 \quad$ Expressed willingness to use items}

3 Please imagine

4 - that level 3 mandatory water restrictions are in place for the use of tap water (only hand-held hosing of the garden on two days, no watering systems, no refilling swimming pools, no hosing of hard surfaces and vehicles) and

- that both recycled and desalinated water are available to you at the same price as tap water without restrictions.

9 You will now see a list of typical water usage purposes. How likely is it that you would use recycled water and desalinated water for the listed purposes under these

11 circumstances. Please answer separately for the two kinds of water.

\begin{tabular}{|c|c|c|c|c|c|c|}
\hline & \multicolumn{6}{|c|}{ Recycled Water } \\
\hline & $\begin{array}{l}\text { Very } \\
\text { likely }\end{array}$ & $\begin{array}{l}\text { Rather } \\
\text { likely }\end{array}$ & Unsure & $\begin{array}{l}\text { Rather } \\
\text { unlikely }\end{array}$ & $\begin{array}{l}\text { Very } \\
\text { unlikely }\end{array}$ & $\begin{array}{l}\text { Not } \\
\text { applicable }\end{array}$ \\
\hline Watering the garden (flowers, trees, shrubs) & $\square 2$ & $\square 1$ & $\square 0$ & $\square-1$ & $\square-2$ & $\square 999$ \\
\hline Washing clothes, doing laundry & $\square 2$ & $\square 1$ & $\square 0$ & $\square-1$ & $\square-2$ & $\square 999$ \\
\hline Cooking & $\square 2$ & $\square 1$ & $\square 0$ & $\square-1$ & $\square-2$ & $\square 999$ \\
\hline Showering & $\square 2$ & $\square 1$ & $\square 0$ & $\square-1$ & $\square-2$ & $\square 999$ \\
\hline Taking a bath & $\square 2$ & $\square 1$ & $\square 0$ & $\square-1$ & $\square-2$ & $\square 999$ \\
\hline Drinking & $\square 2$ & $\square 1$ & $\square 0$ & $\square-1$ & $\square-2$ & $\square 999$ \\
\hline Brushing teeth & $\square 2$ & $\square 1$ & $\square 0$ & $\square-1$ & $\square-2$ & $\square 999$ \\
\hline Bathing the baby & $\square 2$ & $\square 1$ & $\square 0$ & $\square-1$ & $\square-2$ & $\square 999$ \\
\hline Fish pond or Aquarium & $\square 2$ & $\square 1$ & $\square 0$ & $\square-1$ & $\square-2$ & $\square 999$ \\
\hline Toilet flushing & $\square 2$ & $\square 1$ & $\square 0$ & $\square-1$ & $\square-2$ & $\square 999$ \\
\hline Washing the house, windows, driveways & $\square 2$ & $\square 1$ & $\square 0$ & $\square-1$ & $\square-2$ & $\square .999$ \\
\hline
\end{tabular}




\begin{tabular}{|c|c|c|c|c|c|c|}
\hline Religious / spiritial rituals & $\square 2$ & $\square 1$ & $\square 0$ & $\square-1$ & $\square-2$ & $\square 999$ \\
\hline Watering of garden - vegetables, herbs & $\square 2$ & $\square 1$ & $\square 0$ & $\square-1$ & $\square-2$ & $\square 999$ \\
\hline Washing the car & $\square 2$ & $\square 1$ & $\square 0$ & $\square-1$ & $\square-2$ & $\square 999$ \\
\hline Refilling / topping up the swimming pool & $\square 2$ & $\square 1$ & $\square 0$ & $\square-1$ & $\square-2$ & $\square .999$ \\
\hline Air conditioning & $\square 2$ & $\square 1$ & $\square 0$ & $\square-1$ & $\square-2$ & $\square 999$ \\
\hline Firefighting & $\square 2$ & $\square 1$ & $\square 0$ & $\square-1$ & $\square-2$ & $\square 999$ \\
\hline Irrigation of sports fields & $\square 2$ & $\square 1$ & $\square 0$ & $\square-1$ & $\square-2$ & $\square 999$ \\
\hline Irrigation of golf courses & $\square 2$ & $\square 1$ & $\square 0$ & $\square-1$ & $\square-2$ & $\square 999$ \\
\hline Irrigation of recreational parks & $\square 2$ & $\square 1$ & $\square 0$ & $\square-1$ & $\square-2$ & $\square 999$ \\
\hline
\end{tabular}




\section{References}

Adham, S., Kumar, M. and Pearce, W. H. (2005). Model developed for brakish and reclaimed water Desalination \& Water Reuse 15, 38-46.

Alameddine, I. and El-Fadel, M. (2005). Stack emissions from desalination plants: a parametric sensitivity analysis for exposure assessment Desalination 177, 1529.

Alhumoud, J. M., Behbehani, H. S. and Abdullah, T. H. (2003). Wastewater reuse practices in Kuwait Environmentalist 23, 117.

Baggett, S., Jeffrey, P. and Jefferson, B. (2006). Risk perception in participatory planning for water reuse Desalination 187, 149-158.

Baumann, D. D. (1983). Social acceptance of water reuse Applied Geography 3, 7984.

Baumann, D. D. and Kasperson, R. E. (1974). Public acceptance of renovated waste water: myth and reality, 667-673.

Beder, S. (1989). Toxic Fish and Sewer Surfing. Sydney, Allen \& Unwin.

Bixio, D., De Heyder, B., Joksimovic, D., Chikurel, H., Aharoni, A., Miska, V., Muston, M., Schäfer, A. and Thoeye, C. (2005). Municipal wastewater reclamation: where do we stand? An overview of treatment technology and management practice Water Science \& Technology: Water Supply 5, 77-85.

Braga, O., Smythe, G. A., Schafer, A. I. and Feitz, A. J. (2005). Steroid estrogens in ocean sediments Chemosphere 61, 827-833.

Bruvold, W. H. (1972). Public attitues towards reuse of reclaimed water. In Contribution 137, pp. Contribution 137. California: University of California, Water Resource Centre.

Bruvold, W. H. (1979). Human perception and evaluation of water quality. In CRC Critical Reviews in Environmental Control 5, pp. 153-231.

Bruvold, W. H. (1988). Public opinion on water reuse options Journal WPCF 60, 4549.

Bruvold, W. H., Olson, B. H. and Rigby, M. (1981). Public policy for the use of reclaimed water Environmental Management 5, 95-107.

Bruvold, W. H. and Ward, P. C. (1970). Public attitudes toward uses of reclaimed wastewater Water \& Sewage Works, 120-122.

Carley, R. L. (1985). Wastewater reuse and public opinion Journal of American Waterworks Association 77, 72.

Comrie, D., Evans, S., Gale, R. and Kitney, P. (2003). Taste and odour in drinking water: a perception versus reality case study. In OzWater 2003. Perth, WA.

Côté, P., Siverns, S. and Monti, S. (2005). Comparison of membrane-based solutions for water reclamation and desalination Desalination 182, 251-257. 
Dawoud, M. A. (2005). The role of desalination in augmentation of water supply in GCC countries Desalination 186, 187-198.

Dishman, C. M., Sherrard, J. H. and Rebhun, M. (1989). Gaining public support for direct potable water reuse Journal of Professional Issues in Engineering 115, 154-161.

Dreizin, Y. (2006). Ashkelon seawater desalination project - off-taker's self costs, supplied water costs, total costs and benefits Desalination 190, 104-116.

Einav, R. and Lokiec, F. (2003). Environmental aspects of a desalination plant in Ashkelon Desalination 156, 79 - 85.

Gallup, G. J. (1973). Water quality and public opinion Journal of American Waterworks Association 65, 513.

Hamilton, G. R. (1994). Attitudes to potable reuse of reclaimed wastewater. In Recycled Water Seminar, pp. 100-107. Newcastle.

Hanke, S. H. and Athanasiou, R. B. (1970). Social psychological factors related to the adoption of reused water as a potable water supply. In Western resources conference, pp. 113-124. Boulder, Colorado.

Hartley, T. W. (2006). Public perception and participation in water reuse Desalination 187, 115-126.

Heberer, T. (2002). Tracking persistent pharmaceutical residues from municipal sewage to drinking water Journal of Hydrology 266, 175-189.

Higgins, J., Warnken, J., Sherman, P. P. and Teasdale, P. R. (2002). Surveys if users and providers of recycled water: quality concerns and directions for applied research Water Research 36, 5045-5056.

Hinkebein, T. E. and Price, M. K. (2005). Progress with the desalination and water purification technologies US roadmap Desalination 182, 19-28.

Hurliman, A. and McKay, J. (2003). Community attitudes to an innovative dual water supply system at Mawson Lakes South Australia. In OzWater 2003. Perth, Western Australia.

Hurlimann, A. and McKay, J. (2007). Urban Australians using recycled water for domestic use - An evaluation of the attributes of price, saltiness, colour and odour using conjoint analysis Journal of Environmental Management 83, 93104.

IDA (2006). IDA Worldwide Desalting Plant Inventory. In No 19 in MS Excel format. Oxford, UK: Media Analytics Ltd.

International Water Management Institute (IWMI) (2006). Insights from the Comprehensive Assessment of Water Management in Agriculture. In Stockholm World Water Week. Colombo, Sri Lanka.

Johnson, J. F. (1979). Renovated waste water: an alternative supply of municipal water supply in the United States. In University of Chicago, Department of Geography Research Paper No.135.

Kaercher, J. D., Po, M. and Nancarrow, B. E. (2003). Water recycling community discussion meeting I (Unpublished Manuscript). In Australian Research Centre for Water in Society. Perth. 
Kasperson, R. E., Baumann, B., Dwarkin, D., McCauley, D., Reynolds, J. and Sims, J. (1974). Community adoption water reuse system in the United States. In. Washington, DC: Office of Water Resources Research, US Dept. Interior.

Lake, P. S. and Bond, N. R. (2006). Australian futures: freshwater ecosystems and human water usage Futures in press.

Lattemann, S. (2003). Guidelines for the Environmental Sound Management of Seawater Desalination Plants in the Mediterranean Region. In UNEP/MAP/MEDPOL, Sea Water Desalination in the Mediterranean: Assessment and Guidelines. MAP Technical Reports Series No. 139 (UNEP/MAP). Athens.

Lattemann, S. (Submitted). WHO guidance on desalination: Results of the work group on environmental impacts. In Proceedings of the IDA World Congress on Desalination and Water Reuse. Maspalomas, Gran Canaria, Spain.

Lattemann, S. and Höpner, T. (2007). Environmental impact and impact assessment of seawater desalination Desalination In Press, 1-15.

Marks, J., Cromar, N., Fallowfield, H., Oemcke, D. and Zadoroznyj, M. (2002). Community experience and perceptions of water reuse. In IWA World Water Congress. Melbourne.

Marks, J. S. (2003). The sociology of "disgust" towards the use of reclaimed water. In Water Recycling Australia 2nd National Conference (S. I. A. Australian Water Association, National Water Recycling Forum), pp. 1-11. Brisbane, Queensland, Australia.

Marks, J. S. (2006). Taking the public seriously: the case of potable and non potable reuse Desalination 187, 137-147.

Marks, J. S., Martin, B. and Zadoroznyj, M. (2006). Acceptance of water recycling in Australia: National baseline data Community Consultation, 151-157.

Meerganz von Medeazza, G. L. (2005). "Direct" and socially-induced environmental impacts of desalination Desalination 185, 57-70.

Milliken, J. G. and Lohman, L. C. (1985). Analysis of baseline survey: Public attitudes about Denver water and wastewater reuse Journal of American Waterworks Association 77, 72.

Olson, B. H., Henning, J. A., Marshack, R. A. and Rigby, M. G. (1979). Educational and social factors affecting public acceptance of reclaimed water. In Water Reuse Symposium, pp. 1219-1231. Denver, Colorado.

Po, M., Kaercher, J. D. and Nancarrow, B. E. (2004). Literature review of factors influencing public perceptions of water reuse. In CSIRO Land and Water.

Raluy, G., Serra, L. and Uche, J. (2006). Life cycle assessment of MSF, MED and RO desalination technologies Energy in press.

Russell, S. (2004). Community responses and consultation. In. Wollongong: University of Wollongong.

Sims, J. H. and Baumann, D. (1974). Renovated waste water: The question of public acceptance Water Resources Research 10, 659-665. 
Stone, R. and Kahle, R. (1974). Wastewater Reclamation. In Socio Economics, Technology and Public Acceptance. Washington, DC: Office of Water Resource Research, US Department of the Interior.

4 Strang, V. (2004). The meaning of water. Berg.

Sumpter, J. P. (2005). Endocrine disrupters in the aquatic environment: an overview Acta Hydrochimica Hydrobiologica 33, 9-16.

7 Suzuki, D. (1997). The sacred balance. Allen \& Unwin.

8 Ternes, T. A., Stumpf, M., Mueller, J., Haberer, K., Wilken, R.-D. and Servos, M. (1999). Behavior and occurrence of estrogens in municipal sewage treatment plants - I. Investigations in Germany, Canada and Brazil The Science of the Total Environment 225, 81-90.

Thomas, J. F. and Syme, G. J. (1988). Estimating resiential price elasticity of demand for water: A contingent valuation approach Water Resource Research $\mathbf{2 4}$, 1847-1857.

Toze, S. (2006). Water reuse and health risks - real vs. perceived Desalination $\mathbf{1 8 7}$, 41-51.

van Roon, M. (2007). Water localisation and reclamation: Steps towards low impact urban design and development Journal of Environmental Management 83, 437-447.

Weber, W. J. J. (2006). Distributed optimal technology networks: an integrated concept for water reuse Desalination 188, 163-168.

Wintgens, T., Melin, T., Schäfer, A. I., Khan, S., Muston, M., Bixio, D. and Thoeye, C. (2005). The role of membrane processes in municipal wastewater reclamation and reuse Desalination 178, 1-11. 
$1 \quad$ Tables and Figures

Table 1: Segment differences in socio-demographic profiles

\section{Age \\ Mean \\ Std. Deviation \\ Gender \\ Male \\ Female \\ Education}

some secondary school

school certificate

higher school certificate

other college

university (undergraduate)

university (postgraduate)

\section{Occupation}

Clerical or service worker professional

unemployed

retired

manager or administrator

sales

tradesperson

small business owner

home-duties

transport worker

labourer

Favourite TV channel

Channel 4 - WIN

Channel 5 - ABC

Channel 7 - PRIME

Channel 8 - SBS

Channel 10 - ten

Other channel

I do not watch TV frequently

Newspaper use

Mean

Std. Deviation

Switch entire water supply to recycled

water

under no circumstances

not pay anything for my water

pay more than half of the current

pay the same price as I am paying now

pay more for water than I am paying now

Switch entire water supply to desalinated

water

under no circumstances

not pay anything for my water

pay more than half of the current

pay the same price as I am paying now

pay more for water than I am paying now

\begin{tabular}{|c|c|c|}
\hline $\begin{array}{l}\text { General } \\
\text { Strong } \\
\text { accepters }\end{array}$ & $\begin{array}{l}\text { Recycled } \\
\text { Water } \\
\text { Strong } \\
\text { accepters }\end{array}$ & $\begin{array}{l}\text { Desalinated } \\
\text { Water } \\
\text { Strong } \\
\text { accepters }\end{array}$ \\
\hline 46.2 & 45.3 & 44.9 \\
\hline 13.9 & 14.5 & 14.2 \\
\hline 58 & 55 & 57 \\
\hline 42 & 45 & 43 \\
\hline 8 & 11 & 4 \\
\hline 9 & 14 & 14 \\
\hline 18 & 15 & 17 \\
\hline 11 & 8 & 8 \\
\hline 15 & 17 & 12 \\
\hline 22 & 20 & 24 \\
\hline
\end{tabular}

Others p-value

42.6

14.8

45

55

15

10

19 
Figure 1: Comparative perceptions/knowledge about environmental issues

$\square$ Evaluations of recycled water

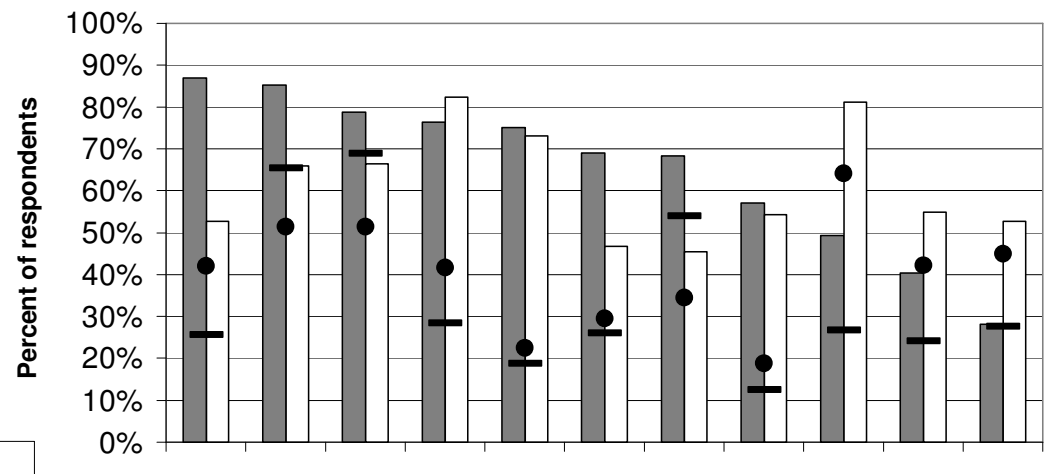

$\square$ Evaluations of desalinated water

- Evaluations of tap water

- Evaluations of bottled water
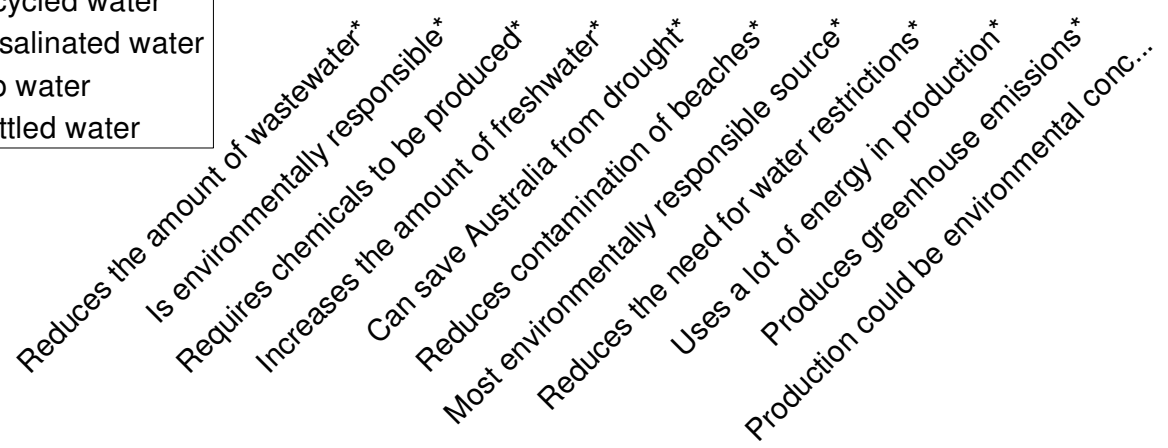
Figure 2: Comparative perceptions/knowledge about health issues

2

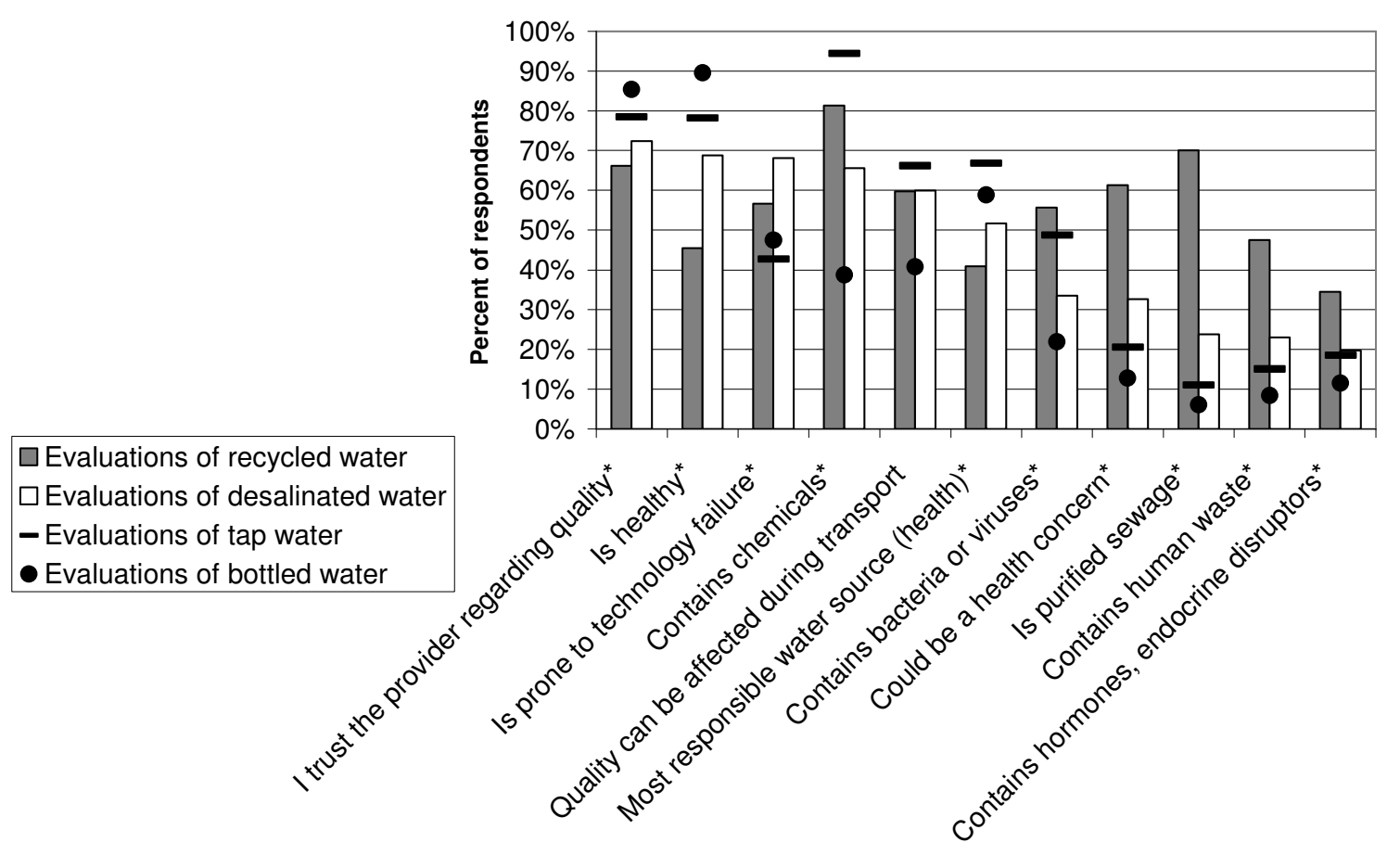

3 
Figure 3: Comparative perceptions of general nature

2

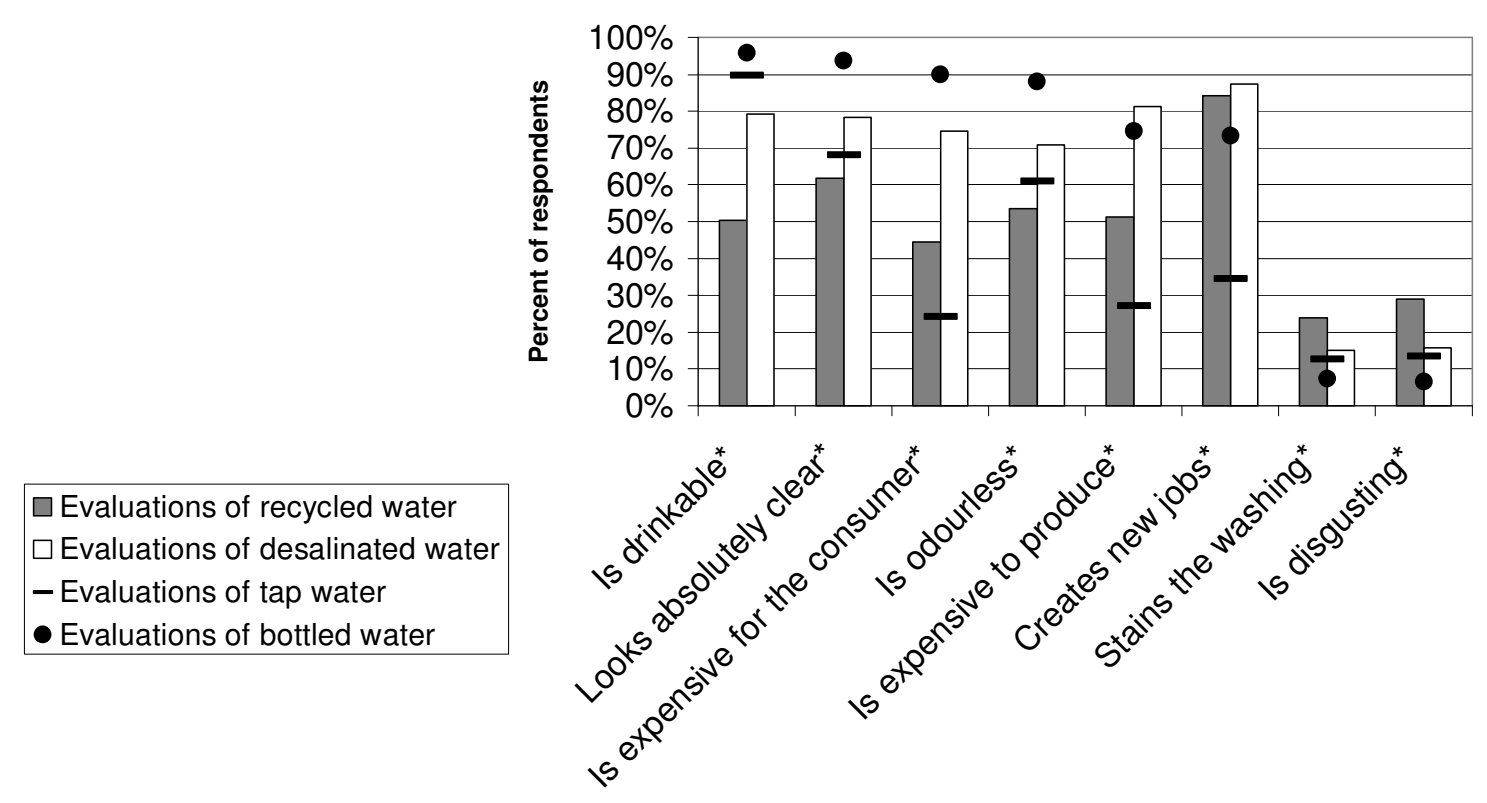

3

4

5 


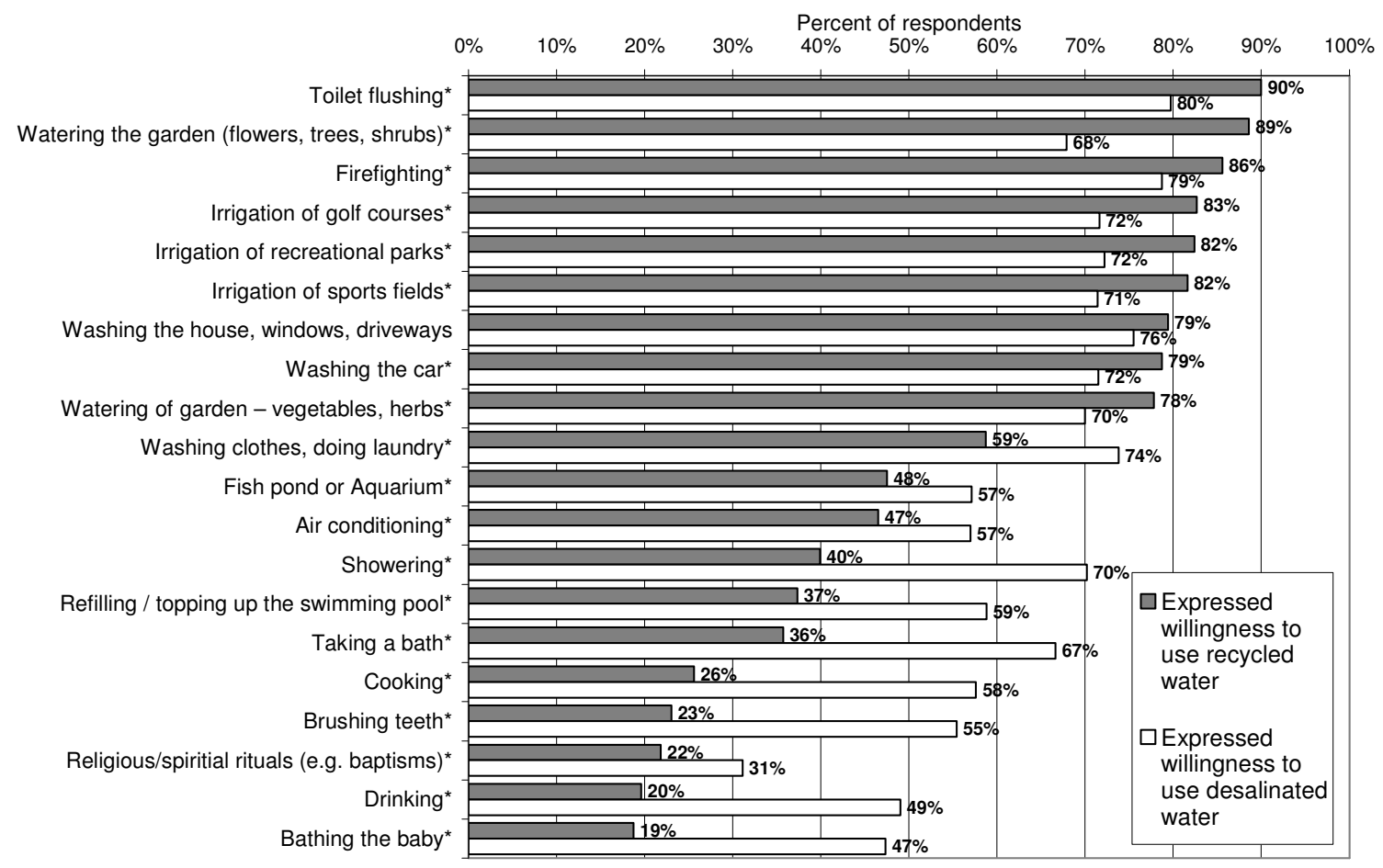


2

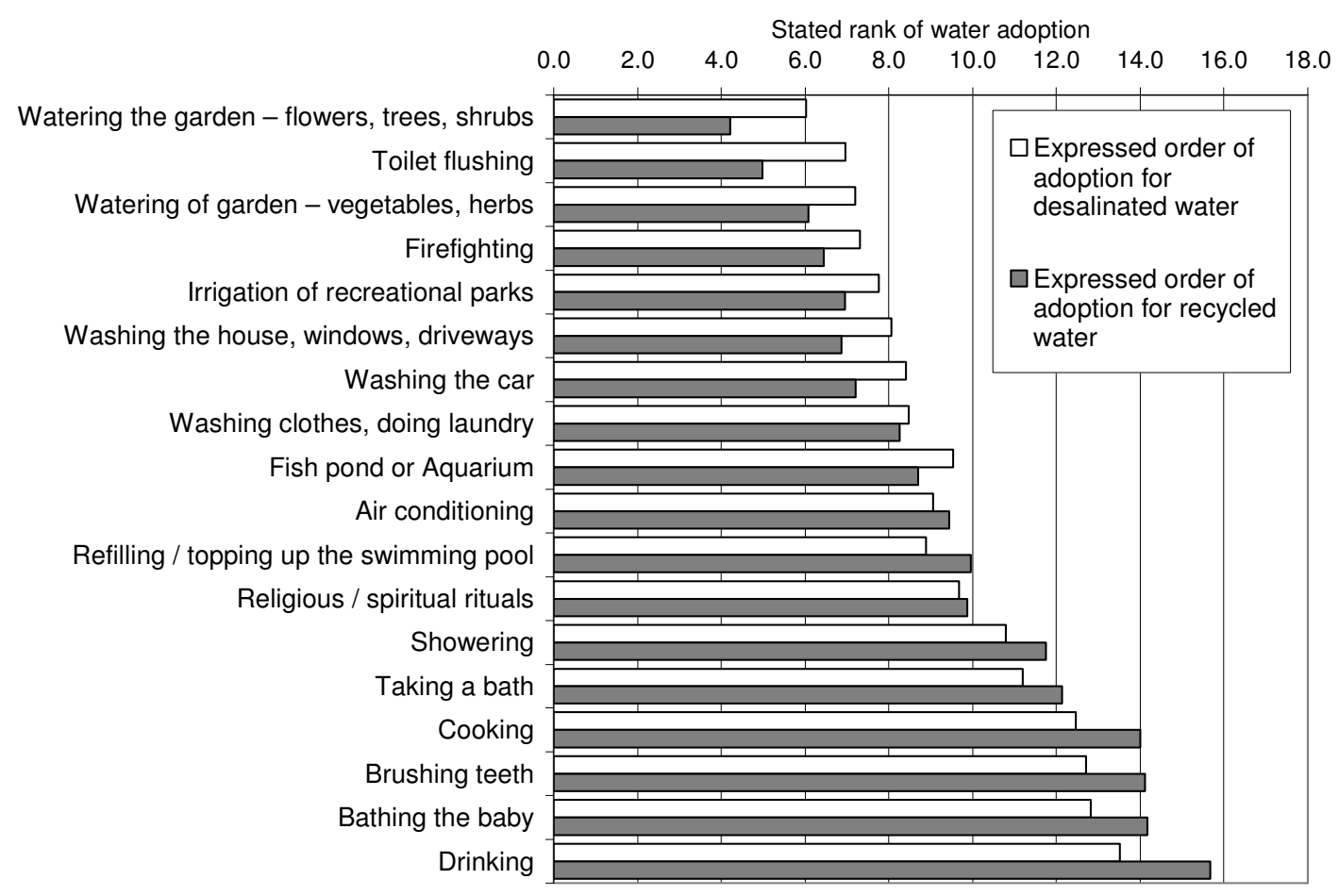

